\title{
MARCAS DE FUNDO DE PASTO: UM MODO DE VIVER QUE AINDA PERSISTE NA MEMÓRIA NAS TERRAS ENTRE OS INSELBERGUES E LICURIZAIS NAS CAATINGAS DA BAHIA, BRASIL
}

\author{
FUNDO DE PASTO OF BRANDS: A WAY OF LIVING THAT STILL PERSISTS IN \\ MEMORY ON THE LANDS BETWEEN INSELBERGS AND LICURI PALMS CAATINGAS \\ OF THE STATE OF BAHIA, BRAZIL
}

Aurélio José Antunes de CARVALHO ${ }^{1}$; Michele dos Santos CONCEIÇÃO ${ }^{2}$; Luiz Alexandre Brandão FREIRE ${ }^{3}$; Gabriel TROILO ${ }^{4}$; José Jackson de Souza ANDRADE ; Erasto Viana Silva GAMA ${ }^{1}$; Antônio Ramos da HORA NETO ${ }^{6}$

\footnotetext{
${ }^{1}$ Instituto Federal de Educação, Ciência e Tecnologia Baiano, Grupo de Pesquisas e Estudos sobre Lavouras Xerófilas - XERÓFILAS, Santa Inês, Bahia, Brasil. *aureliocarva@hotmail.com, erasto.gama@ifbaiano.edu.br; ${ }^{2}$ Universidade do Estado da Bahia - Campus XXII, bolsista CNPq do CVT Fundos de Pasto, Euclides da Cunha, Bahia, Brasil. michelleconceicao13@gmail.com; ${ }^{3}$ Universidade Estadual do Sudoeste da Bahia (UESB), Bahia, Brasil. alexandrefreireuesb@gmail.com; ${ }^{4}$ Secretaria de Educação do Estado da Bahia (SEEBA), Grupo de Pesquisas e Estudos sobre Lavouras Xerófilas - XERÓFILAS, Monte Santo, Bahia, Brasil. gabriel.ogabiru@ gmail.com; ${ }^{5}$ Universidade Católica do Salvador, Instituto de Filosofia e Ciências Humanas, Departamento de Geografia e Cartografia, Grupo de Pesquisas e Estudos sobre Lavouras Xerófilas - XERÓFILAS, Salvador, Bahia, Brasil. jacksonamargosa@gmail.com;

${ }^{6}$ Associação dos Produtores e Produtoras da Agricultura Familiar do Ouricuri do Jatobá (APOJ), Milagres, Bahia, Brasil. apojneto@gmail.com
}

RESUMO: O presente trabalho se constitui numa proposta de averiguação da existência de remanescentes de comunidades tradicionais de Fundos de Pasto nas caatingas com inselbergues e licurizais, entre os Territórios de Identidade do Vale Jiquiriçá e Piemonte do Paraguaçu, municípios de Brejões, Iaçu, Irajuba, Itatim, Milagres, Nova Itarana e Santa Teresinha, no Estado da Bahia, Brasil. Para tanto, foi realizado um apanhado com o apoio de acervo bibliográfico de vários campos do conhecimento: história, geografia, biologia, agronomia, zootecnia e antropologia, de modo a auxiliar na exposição e análise da ocupação do território mencionado; e tomada de dados junto à população local. Assim, por meio de entrevistas semiestruturadas aplicadas junto a informantes idosos e lideranças de meia idade no citado território foco, e em comunidades tradicionais de Fundo de Pasto, em Brotas de Macaúbas e Monte Santo, nota-se que o processo colonizatório, nessa região, durou quatro séculos com a atividade pastoril de rebanhos de gado solto, perdurando até o início da segunda metade do século XX. Entretanto, ao ser encetada a lei do Pé Alto ou lei dos Quatro-fios, desestruturam-se formas seculares de vida e cultura, perceptíveis na memória de pessoas acima dos 60 anos na mencionada região. Na prática pastoril, identificaram-se as marcas ou os sinais realizados nos animais por meio de cortes feitos com faca nas orelhas dos criatórios, e cada um desses possui nomenclatura específica. Esses sinais serviam de "assinaturas" distintivas de famílias/pessoas, nos criatórios que forrageavam em áreas sem cercas. Tais práticas permanecem em comunidades de Fundo de Pasto, em Monte Santo e Brotas de Macaúbas, e presentes na memória de pessoas, entre os vales mencionados no pediplano sertanejo da região de Milagres. Possivelmente, seja um indicativo de práticas de remanescentes de comunidades tradicionais de Fundo de Pasto, exemplo de Jatobá (Milagres) e Traíras (Itatim), remontando a um passado recente de criação em regime de solta. O cercamento das terras contribuiu para a rápida extinção de raças crioulas, no território exposto no trabalho, assim como para maiores impactos socioambientais, concentração de terras, êxodo rural e perdas de práticas ancestrais de manejo de rebanhos, que expunham tais comunidades na atual categoria Fundo de Pasto. Evidenciam-se semelhanças nas comunidades dos territórios mesmo que disjuntos, afastados cerca de $400 \mathrm{~km}$.

Palavras-chaves: comunidades tradicionais, inselbergue, lei dos quatro-fios, práticas ancestrais, semiárido

\begin{abstract}
The present work constitutes a proposal to investigate the existence for remnants of traditional communities Fundo de Pasto in the caatingas with inselbergs and licuri palm between the Identity Territories of the Jiquiriçá Valley and Piemonte do Paraguaçu, municipalities of Brejões, Iaçu, Irajuba, Itatim, Milagres, Nova Itarana and Santa Teresinha, in the state of Bahia, Brazil. To this end, a survey was carried out with the support of a bibliographic collection from various fields of knowledge: history, geography, biology, agronomy, zootechnics, anthropology in order to assist in the exposure and analysis of the occupation of the fore mentioned territory of data collection with the population local. Thus, semi-structured interviews were applied to elderly and/or middle-aged informants in the mentioned focus territory and in Traditional Communities of Fundo de Pasto in Brotas de Macaúbas and Monte Santo, state of Bahia. It is noted that then colonization process in this region lasted four centuries with the pastoral activity of herds of loose cattle, lasting until the beginning of the middle of the 20th century. However, if the High Foot Law or the Four-Wire Law is initiated, secular forms of life and culture are disrupted, which can be seen in the memory of people over 60 in the afore mentioned region. In pastoral practice, the marks or signs made on the animals were identified through cuts made with a knife in the ears of the farms and each of these specific nomenclatures. These signs served as distinctive "signatures" of families / people in the farms that foraged in areas without fences. Such practices remain in communities of Fundo de Pasto in Monte Santo and Brotas de Macaúbas and present in the memory of people among the valleys mentioned in the back land pediplano of the Milagres region. Possibly, it is an indication of the practices of remnants of traditional communities of Fundo de Pasto, example of Jatobá (Milagres) and Traíras (Itatim), going back to a recent past of breeding on a loose basis. The fencing of the lands corroborated for the rapid extinction of Creole breeds in the territory exposed at work, greater socio-environmental impacts, concentration of the land, rural exodus and losses of ancestral herd management practices that exposed these communities in the current category: Fundo de Pasto. Similarities are evident in the communities of the territories, even if disjointed and around $400 \mathrm{~km}$ away. Keywords: traditional communities, inselberg, four-wire law, ancestral practices, semiarid
\end{abstract}


"Os bezerros - todos orelhas redodinhamente furadas, no meio, ambas". "Um boi preto estrelo. Não é boi de carro: é boi boiadeiro Deu trabalho para nós pegar ele, Nessa pega agora."

A Boiada (manuscritos) Guimarães Rosa (1908-1967)

\section{ABRINDO PASSADIÇOS}

Passear pela tradição oral nordestina, na "gesta de boi" ou "gesta de gado", ou por narrativas impressas nos cordéis do Nordeste do Brasil (PEREIRA, 2017), como na História do Boi Misterioso, de Leandro Gomes de Barros - na passagem do século XIX para o início do século XX - ajuda a compreender a sociedade agrária no semiárido. Isso também ocorre quando se envereda pelos sertões de Guimarães Rosa, o qual traz à tona um modo de vida (os vaqueiros, as pegas de gado, as apartações, as marcações - registros feitos nas orelhas dos criatórios soltos - ou ferrar os bovinos, procedimentos que faziam parte do manejo tradicional).

Com efeito, são narrativas bem singulares, que abrigam reminiscências de um passado que transpassa o Atlântico, caminha pela Península Ibérica, nos Compascuum, sua colonização romana que advém de civilizações anteriores, como a grega e a egípcia, em que há relatos segundo as quais membros dessas culturas já marcavam ou ferravam seu gado (ARAÚJO et al., 2006; DINIZ, 2008). Tal prática está presente tanto nas comunidades tradicionais de Fundo de Pasto, assim reconhecidas, como em outras assemelhadas nas caatingas e cerrados baianos, onde a pata do gado foi o rastro de sua territorialização agropastoril, impressa a partir dos colonizadores.

$\mathrm{O}$ presente trabalho foi tecido, portanto, a partir de vários campos dos saberes/conhecimentos, a fim de melhor compreender práticas agropecuárias dentro do contexto de um território camponês, que advém de uma territorialidade, entendido enquanto: "O esforço coletivo de um grupo social para ocupar, usar, controlar e se identificar com uma parcela específica de seu ambiente biofísico" (LITTLE, 2002, p. 253), dependente de contingências históricas, marcadas por processos de múltiplas faces (conflitos, acomodações, ajustes, pactos sociais, forma de uso e propriedade da terra, memória coletiva, afetividades, práticas de lidar com os animais e plantas, valores e crenças) a fim de permanecer em um local, defender-se e estabelecer-se como um território. Salienta-se que o contexto e o território locus do presente trabalho pouco foram estudados, portanto, há poucos registros realizados de modo multidisciplinar e com inserção dos saberes e das memórias de sujeitos locais.

Com efeito, a construção de um território se dá, fundamentalmente, a partir da percepção do poder instituído por um grupo social em determinado espaço (NEVES, 2019). No caso da colonização da América Portuguesa, instituiu-se uma série de regimentos, regulamentos, instrumentos, recursos, além de costumes consuetudinários e uma trama de relações sociais que viabilizou a ocupação do vasto território presente em seus domínios. A lógica da colonização, portanto, teve seus alicerces na reterritorialização das terras que antes eram ocupadas pelos povos nativos do Brasil (PRADO JÚNIOR, 2008).

Decerto, a ocupação econômica das terras fronteiriças entre o Médio Paraguaçu e as mediações da Zona da Mata no Recôncavo Sul, delimitado aos domínios dos atuais municípios de Brejões, Iaçu, Irajuba, Itatim, Milagres, Nova Itarana e Santa Teresinha precedeu uma série de conflitos heterogêneos que, intensificados no século XVII tomaram na historiografia o nome de Guerra dos Bárbaros; era, portanto, a luta dos ditos civilizados colonos contra o atraso promulgado pelos indígenas que habitavam essas áreas (CUNHA, 1992; PUNTONI, 2002). Inclusive, a Vila de João Amaro, hoje distrito de Iaçu, foi resultado de uma doação régia para o filho de Estevão Ribeiro Baião Parente, João Amaro Maciel Parente, em fins do século XVII. Durante os séculos XVIII e XIX, a vila seria um importante pouso para quem se deslocasse do Recôncavo em direção às estradas que conduziam para Minas Gerais e Minas do Rio das Contas.

Constitui-se objeto deste trabalho a averiguação da existência de remanescentes de comunidades tradicionais de Fundos de Pasto, nas caatingas com inselbergues e licurizais, numa área entre os atuais Territórios de Identidade do Vale Jiquiriçá e Piemonte do Paraguaçu, abarcando os municípios de Brejões, Iaçu, Irajuba, Itatim, Milagres, Nova Itarana e Santa Teresinha, no Estado da Bahia, Brasil. Isso, a fim de que os grupos existentes nessas localidades e a sociedade em geral possam ser 
informados acerca da formação histórica do território, seu modus operandi de vida, sua relação com o ambiente, a conservação da Caatinga, os criatórios e as raças crioulas, contribuindo para ressignificar formas de luta e fortalecer essas comunidades. Para tanto, fez-se necessário um passeio de caráter multidisciplinar determinante na formação do território e sua cosmografia (LITTLE, 2002), tendo como objeto da investigação em campo elementos de caráter popular (práticas de lidar com o rebanho), como a marcação dos animais que era inerente ao uso da terra em regime agropastoril desprovido de cercas, com os criatórios soltos nas caatingas.

\section{CARREIRO METODOLÓGICO}

\section{A demarcação da área de estudo}

A delimitação da área de estudo foi estabelecida recortando uma porção da paisagem do pediplano sertanejo, entre os Vales do Jiquiriçá e Paraguaçu, partindo de uma poligonal que tem o distrito de João Amaro, município de Iaçu, como ponto de saída e de chegada, atravessando divisores de águas do Riacho do Salgado, da Serra das Canoas e do Jatobá até proximidades da Serra da Jibóia (Pedra Branca), embeiçado à margem direita do Paraguaçu, perfazendo cerca de $3.200 \mathrm{~km}^{2}$, ou seja, 320.000 ha (Figura 1). Assim, tomamos como referência, dentre outros aspectos, a área do pediplano sertanejo entre os Vales do Paraguaçu e do Jiquiriçá, englobando o riacho do Salgado - limite a sudoeste - ao cortar a região da Mata Atlântica, recebe o nome de Jiquiriçá Mirim ou Ribeirão, principal afluente do rio Jiquiriçá.

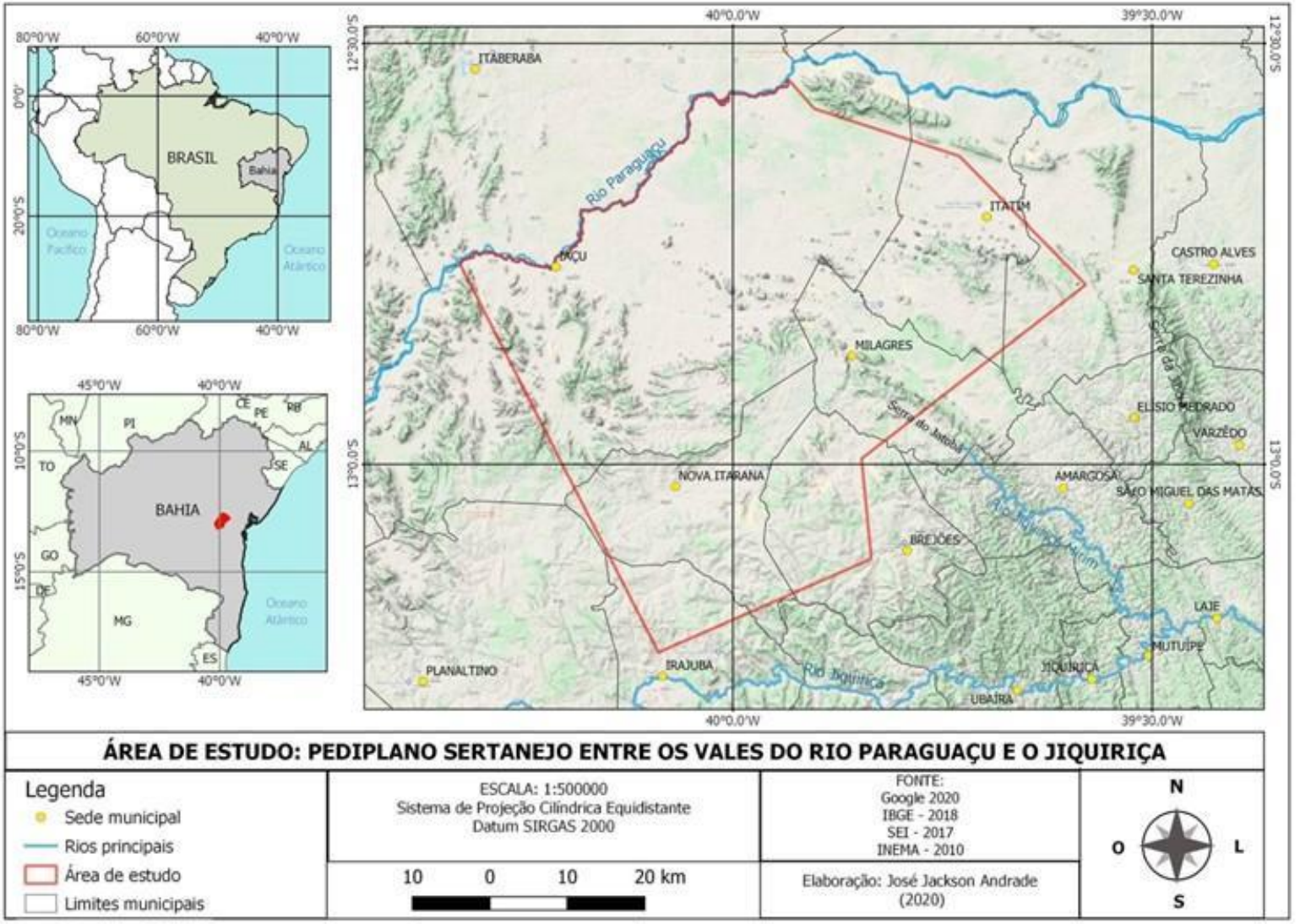

Figura 1: Mapa da área de estudo envolvendo um recorte do pediplano sertanejo e inselbergues na Bahia entre os Vales do Jiquiriçá e Paraguaçu. Elaboração: José Jackson Andrade, 2020.

Em sua maior parte, a área estudada compreende a unidade geomorfológica denominada Pediplano Sertanejo, que, de acordo com Brasil (1981), corresponde a uma superfície deprimida, cercada por relevos planálticos de unidades adjacentes, com altitudes entre 400 e $600 \mathrm{~m}$. Trata-se de grandes extensões quase planas, onde os interflúvios constituem pediplanos mais ou menos conservados com presença de notáveis campos de inselbergues cristalinos (AB'SÁBER, 1971). Esses aplainamentos se desenvolveram sobre litologias do Pré-Cambriano Indiferenciado e Inferior, constituídas principalmente de gnaisses, migmatitos, charnockitos, metatexitos, além de intrusões de granitos (BRASIL, 1981). 
De acordo com Ab'Sáber (2003), inselbergues são acidentes geográficos proeminentes que resistiram aos processos intempéricos que provocaram o aplainamento do relevo, ocorrido no fim da era terciária e início do quaternário. Os morrotes que exibem os inselbergues são recorrentes, em Itatim, Milagres e Iaçu, formados por pedimentos e pediplanos, conforme modelagem da morfologia evolutiva preconizada pelo pesquisador Lester King (1956). Santos e Salgado (2010), descrevendo os aspectos morfológicos da região de Milagres - BA, afirmam que as formas mais características do modelado de relevo, na região, são os inselbergues, morros residuais (arredondados sem vegetação), as cristas agudas ou arredondadas, os lajedos e o rebordo do planalto. Além disso, sobre o planalto veemse o entalhamento claramente definido de trechos com inexpressiva amplitude topográfica bem como a presença de topos arredondados, com superfícies quase planas, com destaque para os pedimentos conservados, que representam o modelado mais característico da área de Milagres.

Os solos, em sua maioria, são arenosos de fertilidade baixa, Neossolos regolíticos e planossolos com algumas manchas de solos ARGILOSOS e avermelhados de melhor fertilidade (Cambissolos ou argissolos) (INEMA, 2014; SIBCS, 2018), chegando às proximidades da Serra da Jiboia, que foi ocupado pelos colonizadores cuja demarcação se deu com a Casa Forte, construída no século XVI, relatado por Gabriel Soares de Sousa, no Tratado descritivo do Brasil de 1587 (1987).

A Serra da Jibóia é um divisor de águas, de onde surgem mais 40 nascentes, formando cerca de 15 riachos, que contribuem para quatro bacias da Bahia: rio da Dona, rio Jaguaripe, rio Jiquiriçá e rio Paraguaçu (BLENGINI et al., 2015). Por conta disso, a Serra era chamada pelos indígenas de Guariru, depósito de águas (REGO, 2009; BLENGINI et al., 2015). Portanto, constitui-se um divisor de águas entre os vales citados, ocupado por dois tipos vegetacionais: a Caatinga, na área referente ao sotavento, com menores índices de chuvas, em torno de $600 \mathrm{~mm}$ anuais, e a Mata Atlântica, na face leste, barlavento, com chuvas orográficas e alta pluviosidade acima de $1.200 \mathrm{~mm}$ anuais.

Com exceção dos rios Paraguaçu e Jiquiriçá, a drenagem na área de estudo apresenta-se em sua maior parte intermitente. De acordo com Ab'Sáber (1971), isso está relacionado com o ritmo desigual e pouco potente das precipitações nas áreas em questão. Por sua vez, a cobertura vegetal dessa região compreende uma caatinga bastante rica em cactos e.g., mandacaru (Cereus jamacaru), xique-xique (Pilosocereus gounenellei), cabeças-de-frade (Melocactus sp.) e leguminosas nativas forrageiras para o gado, como catingueira (Poincianella pyramidalis), jurema (Mimosa tenuiflora), monzê (Albizia polycefala); e com presença de palmeiras: licuri (Syagrus coronata) e ariri ou licurioba (S. vagans), sendo também com abundância cansanção ou favela (Cnidoscolus obtusifolium), pau-de-colher (Monteverdia rigida) e Myrtaceae, dentre outras (CARVALHO, 2019).

\section{No trecho do carreiro metodológico}

O carreiro ou percurso metodológico adotado contou com apoio de acervo bibliográfico apanhado de vários campos do conhecimento: literatura, história, geografia, agronomia, zootecnia e antropologia de modo a auxiliar na exposição e análise da ocupação do território em foco (Figura 1), cuja área de $3.200 \mathrm{~km}^{2}$.

Utilizou-se enquanto instrumento metodológico entrevistas semiestruturadas (THIOLLENT, 2000; VERDEJO, 2010), cujo fio condutor do roteiro foram conversas em torno das criações soltas na Caatinga, do uso da terra, do manejo dos rebanhos e da existência de marcas distintivas nos rebanhos. Junto a agricultores mais idosos e lideranças, foram totalizados 13 informantes, sendo seis em Monte Santo, cinco em Milagres, um em Itatim e um em Brotas de Macaúbas - BA.

Os informantes foram pessoas mais idosas das comunidades, e algumas lideranças de meia idade, pertencentes às comunidades, tomando como critério de escolha as memórias sobre a ocupação do território e as práticas cotidianas de manejo das criações. Em Monte Santo e Brotas de Macaúbas, as entrevistas foram realizadas em Comunidades Tradicionais de Fundo de Pasto. Em Milagres e Itatim, foram realizadas em localidades com características similares a tais comunidades. As narrativas foram registradas com inserção de desenhos ilustrativos e vídeos por meio de telefone móvel, descrevendo as diferentes formas de sinalização (marcação) de criatórios. Ressalta-se que os municípios de Milagres e Itatim situam-se a cerca de $400 \mathrm{~km}$ dos demais.

\section{ARREBANHANDO ACHADOS}

Nos currais, tocando o gado pelo sertão de perneira e gibão

De fato, o pastoreio e a introdução do gado vacum nos sertões da Bahia datam de meados do século XVI. Atingiram locais mais distantes no século posterior, quando um circuito de produção de estradas 
e de intercâmbios começou a dar sinais de maior solidez, ante as dificuldades promovidas pelo meio físico, pela resistência dos indígenas e pelos esparsos recursos que compunham a ocupação das terras interioranas. O gado bovino, portanto, tinha papel fundamental na delimitação de fronteiras móveis e na ocupação dessas terras, sendo, ao mesmo tempo, meio de transporte de pessoas e cargas, produção de carne e couro para áreas de produção de lavoura na colônia e.g., cana-de-açúcar, algodão e mandioca, onde havia restrições aos criatórios (SIMONSEN, 2005; PRADO JÚNIOR, 2008). Dada a relevância da marca da atividade extensiva agropastoril, na ocupação no interior do território do Brasil colonial, o período foi cunhado de "Civilização do Couro" (ABREU, 1934).

A territorialização significa a ocupação e a utilização histórica de um espaço, observando suas transformações socioeconômicas e políticas. A partir dessas premissas, foi estabelecida uma teia de poderes derivados de interesses comuns (SANTOS, 2008), arranjados em laços consanguíneos, econômicos e culturais que fundamentaram as bases de uma sociedade de classes bem estratificada. Para aqueles que se aventuravam pelas serras, pelos rios, pelas matas e pelas zonas do semiárido baiano, a territorialização e a fundamentação das posses portuguesas significavam também prestígio, status de fidalguia e nobiliarquia, aumento do poder político e da clientela (FURTADO, 2006).

Ao rastrear as primeiras incursões, partindo da Vila de Jaguaripe e transpondo a Serra da Jiboia até atingir o rio Paraguaçu, depara-se com a empresa promovida pelo cronista Gabriel Soares de Sousa e seu Irmão João Coelho de Sousa, ainda no século XVI; no início do processo de colonização dos portugueses (AZEVEDO, 2007). Eles partiram do litoral, embrenharam-se pelas matas, cortaram a Serra da Jiboia e se deparam com a Caatinga. Como se sabe, um bioma de vegetação mais rala, portanto, de mais fácil rastreabilidade e de clima mais seco, o que é era mais salutar para os colonizadores e para o gado, em comparação às terras localizadas nas matas (Mata Atlântica), dotadas de clima com alta umidade atmosférica, vegetação adensada e relevo mais acidentado.

As relações baseadas na atividade pecuária já estavam presentes desde a primeira metade do século XVII, nas regiões do Médio Paraguaçu intermediadas pelas Cabeceiras do Paraguaçu, próximas ao Recôncavo. Prova disso é que desde os fins da década de 1650 ocorre o processo de abertura de estrada pelo sargento-mor de Ordenanças Pedro Gomes. Junto a Gaspar Rodrigues Adorno, Pedro Gomes enfrentou os povos indígenas Maracá e Payayá, abrindo a mencionada estrada em 1657:

Pelo Regimento de 3 de outubro de 1657, o sargento-mor Pedro Gomes, juntamente com o capitão Gaspar Rodrigues Adorno, para evitar as hostilidades que os "tapuias" costumavam fazer nas freguesias de Paraguaçu, Jaguaripe e Cachoeira, deveriam fazer algumas casas-fortes com bastante infantaria para destruir as aldeias assegurar a campanha e abrir um caminho de carros de boi desde Cachoeira até a borda da mata da serra do Orobó, atual município de Rui Barbosa, onde seria erguida a primeira casa-forte [...] Para conservar a gente do sertão e manter esta empreitada, o governador Francisco Barreto emitiu uma portaria autorizando ao sargento-mor Pedro Gomes tomar de qualquer curral as cabeças de gado que fossem necessárias para alimentar os trabalhadores e a infantaria, e dar recibos como indenização aos donos e feitores prejudicados. (SANTOS, 2011, p. 155-159).

Como forma de garantir o sucesso da abertura da estrada, as fazendas de gado nas proximidades da extensão da estrada deveriam garantir o sustento das tropas de Gaspar Rodrigues Adorno e de Pedro Gomes. Porém, como essas ações não se fizeram suficientes para enfrentar os Payayá e Maracá nesses espaços limítrofes do Médio Paraguaçu, paulistas como Estevão Ribeiro Baião Parente, Bartolomeu Aires e Brás Rodrigues Arzão foram convocados para os destacamentos militares nessa região (SANTOS, 2011).

Junto ao processo colonizatório, em 1533, chegam os gados bovinos, equinos, muares, caprinos e ovinos e, logo, atingiram primeiro as restingas ao norte de Salvador e do Baixo-Sul (Valença). No início do século XVIII, a atividade da pecuária era tão importante para o abastecimento e a territorialização do semiárido pelos colonizadores, que a Coroa Portuguesa por meio de Carta Régia, determinou que a criação de bovinos e animais para corte ficaria proibida em um raio de dez léguas do litoral. De fato, isso significou um zoneamento produtivo: separou-se a monocultura açucareira que dominava próximo ao litoral das policulturas do sertão e da Zona de Mata (SIMONSEN, 2005). Assim foram surgindo povoações no sertão sob prevalência da atividade agropastoril (NEVES, 2019).

Nos trânsitos de boiadas e tropas estabeleceram-se núcleos populacionais pelo sertão, onde era possível o abastecimento permanente de água. $\mathrm{O}$ gado foi, portanto, um dos principais fatores intervenientes, tanto da conquista do território, quanto da sua ocupação econômica, organização das atividades produtivas e formação social da zona central da Bahia. Após a expulsão dos invasores holandeses, grupos organizados conquistaram os territórios indígenas e os sertões foram paulatinamente ocupados pela pecuária. (NEVES, 2019, p. 15). 
Impulsionados também por restrições impostas e implementadas com relação ao gado, a fim de favorecer as lavouras, alargarem-se os currais pelo interior, pelas caatingas dos Vales dos rios São Francisco, Jacuípe, Itapicuru, Vaza-Barris ao norte, assim como dos rios Paraguaçu, das Contas e Alto Jiquiriçá, a sudoeste de Salvador. Eles se caracterizaram, por quatro séculos, enquanto região pastoril de criatórios de rebanho de gado solto, capitaneados por dois domínios senhoriais: a Casa da Torre, dos D'Ávila e a Casa da Ponte, dos Guedes de Brito (BANDEIRA, 2015).

De volta à nossa área de estudo (Figura 1), de fato, o gado foi a marca de constituição desse território e também era caminho de tropeiros para os sertões da Ressaca e de Minas Velhas do Rio de Contas. As primeiras povoações junto à Serra da Jiboia foram: Pedra Branca e Monte Cruzeiro; e na parte de relevo mais aplainado, distante destas cerca de $25 \mathrm{~km}$, fora erigida a capela de Nossa Senhora da Conceição da Tapera, atual Santa Teresinha, cujo território englobava municípios como Amargosa, Itatim, Iaçu, Milagres, Brejões, Santa Teresinha e Nova Itarana, vinculado aos Guedes de Brito, da Casa da Ponte, que de forma semelhante à Casa da Torre, dos Garcia D'Ávila, dominava uma extensa área de Vila de Jaguaripe, atravessando sertões e atingindo o norte de Minas Gerais.

Indivíduos como Francisco Bruza Espinosa, Vasco Rodrigues de Caldas, Antonio Dias Adorno, Sebastião Fernandes Tourinho, João Coelho de Souza, Gabriel Soares de Sousa, Belchior Dias Moreira, entre outros, buscavam reafirmar suas devoções à Coroa no limiar dos séculos XVI e XVII, esperando pela concessão de mercês e benesses que pudessem solidificar as relações destes e de seus herdeiros com a Metrópole. As relações bilaterais entre esses indivíduos e a Coroa Portuguesa eram pautadas pelas relações de fidalguia e nobiliarquia. Parte dos recursos dessas incursões, em direção aos territórios interioranos da Bahia, era proveniente dos próprios particulares, que ao noticiarem riquezas, bens materiais e possibilidades de culturas, nesses terrenos longínquos do litoral, recebiam em troca a doação de terras, títulos, propriedades e privilégios (FURTADO, 2006).

$\mathrm{O}$ ato de doar, de conceder, na lógica do regime colonial, tinha como pressuposto a formação de laços parentais, de cumplicidade e de arraigamento dos valores de fidalgo, que de um lado recrudesciam suas capacidades socioeconômicas, fortalecendo sua base clientelista e de proteção e, por outro, o indivíduo que recebia essas doações, tutelado por um senhor maior, tinha o início de seu movimento de agregar posses e títulos para o seu seio familiar.

Diante dessa lógica, em obras como a do Padre Azpilcueta Navarro, que acompanhou Espinosa em meados de 1550, e o Tratado descritivo do Brasil, de 1587, oriundo do roteiro instituído por João Coelho de Souza, denotam o processo de reterritorialização, através do cativo das populações indígenas, da inserção de novas formas de trabalho pautadas na servidão e na lógica da subtração de renda da terra.

Territorialização significa, portanto, a tomada e apropriação de um espaço por um grupo alienígena, com o estabelecimento do seu aparato de poder e a instituição de instâncias políticas, econômicas, militares, eclesiásticas e judiciárias. Em consequência, a colonização dessa região, mais do que das outras partes do Brasil resultou de ações beligerantes contra as populações nativas, da conquista e ocupação econômica dos seus territórios, para o estabelecimento de nova ordem político-econômica e sociocultural. (NEVES, 2019, p. 03).

A morfologia agrária, paulatinamente transformada ao longo das décadas e dos séculos, apoiava-se no tripé econômico fundamentado pela relação entre os homens, a terra e as técnicas produtivas; condição imprescindível para a instituição dos laços de posse das terras. Desenhava-se o rearranjo da ordem produtiva, instituído pelas guerras do século XVII que iam desde o Aporá, mediado pela Zona de Mata até a Serra do Orobó, entrecortando o semiárido no Médio Paraguaçu (SANTOS, 2011; LINHARES, 2015).

Nesse contexto, ao fazer um recorte em áreas dos atuais municípios de Itatim, Iaçu, Milagres, Brejões, Irajuba, Nova Itarana e Santa Teresinha, havia extensas áreas de Caatinga com imensos licurizais, o que foi descrito por Bondar (1939). E o aspecto de vias de acesso, relevo, instalações e percepções acerca dos povoados, costumes e paisagens foi bem detalhado por Theodoro Sampaio (1905). Decerto, as grandes fazendas de criatórios soltos de bovinos, caprinos, ovinos, suínos, equinos e muares foram a marca do estabelecimento da colonização. De forma genérica, relatou Caio Prado Júnior (2006, p. 183): "[...] o gado é mais ou menos deixado à lei da natureza, são-lhes dispensadas muito poucas atenções e o maior cuidado consiste em evitar o extravio e reuni-los para ser utilizado".

De fato, os colonizadores introduziram vários tipos de gado e os rebanhos bovinos espalharam-se rapidamente pelo interior. Estavam sob a guarda de vaqueiros livres ou escravos, que estabeleceram 
suas famílias, seus laços familiares e de compadrio entre si e com os donos das terras. Ainda hoje, evidenciam-se na fazenda Bom Jesus, contígua à Fazenda Quixaba, ambas em Milagres - BA, respectivamente, instrumentos de aprisionamento e castigo de escravos e um sobrado secular e imponente, construído sobre um imenso lajedo nas primeiras décadas do século XIX. Provavelmente, um ponto estratégico de pouso para tropeiros do Alto Sertão até o litoral (Figura 2A). Mais à frente, do alto, avista-se, próximo à cidade de Milagres, o Lajedo Alto, grande inselbergue com uma povoação em sua vizinhança de mesmo nome (Figura 2B) e o pediplano com morrotes e inselbergues de Itatim (Figura 2C). Ademais, a região é de povoamento antigo, demonstrado por meio de pinturas rupestres de povos pré-colombianos (Figura 2D).

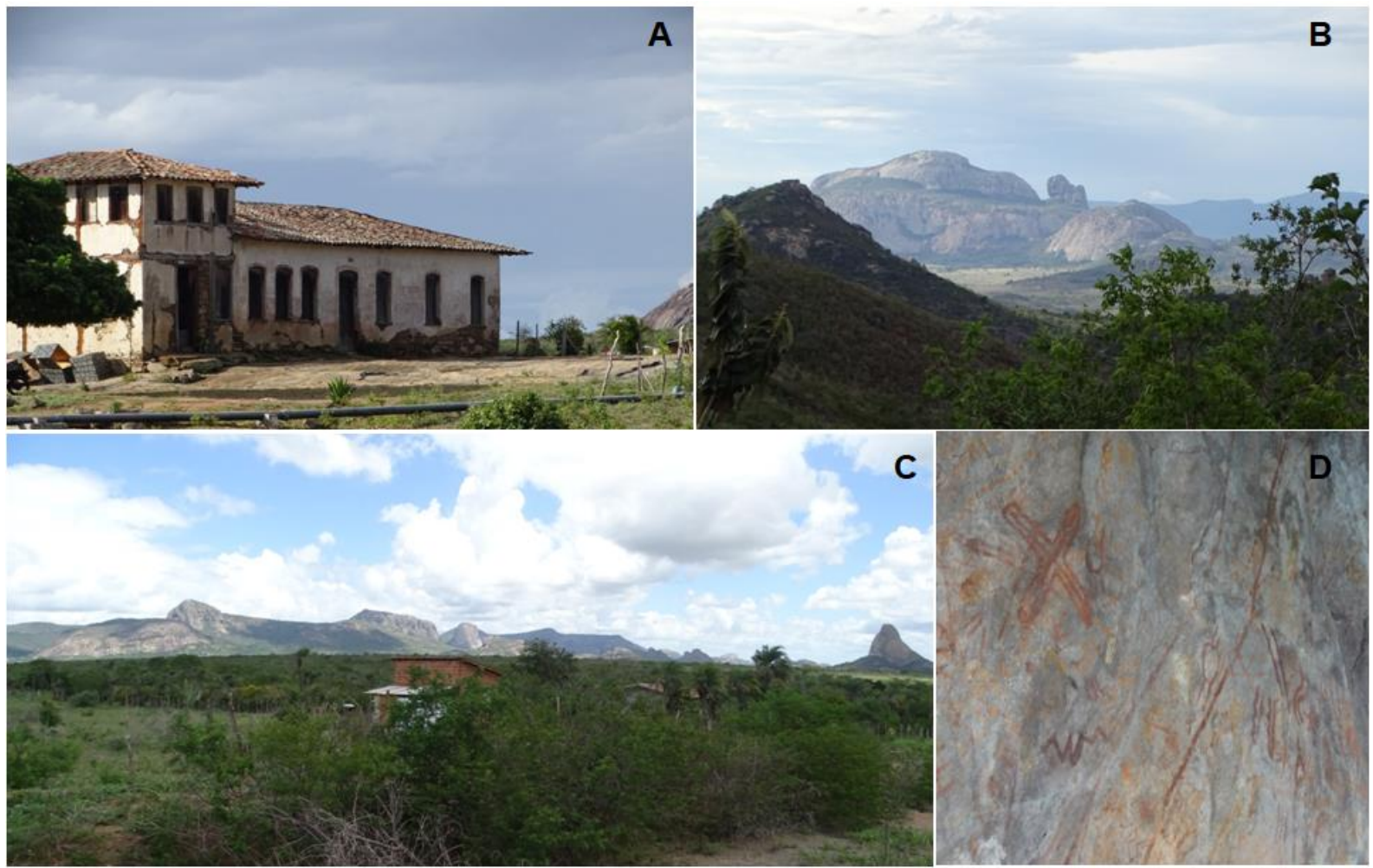

Figura 2: Pediplano sertanejo e inselbergues na Caatinga baiana. (A) sede da Fazenda Quixaba, Milagres - BA; (B) Vista do Lajedo Alto, Iaçu - BA; (C) Paisagem do conjunto de inselbergues em Itatim - BA; (D) Pinturas Rupestres, Fazenda Jatobá, Milagres - BA. Fotos de Aurélio Carvalho (2018).

Acerca da região, no final do século XIX, o engenheiro Theodoro Sampaio, em sua obra $O$ Rio de São Francisco e a Chapada de Diamantina, descreve o longo trecho percorrido no lombo de burros entre Bom Jesus da Lapa e São Félix do Paraguaçu. No transcurso deste, o autor fornece detalhes da Vila de Milagres, disposto no canto esquerdo do mapa elaborado por ele na referida obra (Figura 3):

O povoado constava de uns trinta moradores, junto de uma capella, e tinha o seu commercio animado, como pouso que é dos tropeiros que demandam dos sertões de Maracás, do Brejo Grande, do Bom Jesus dos Meiras, de Caetité e das regiões mais longinquas do norte de Minas e do Valle do S. Francisco. Deste logar, na base da chapada que acabamos de atravessar, avista-se uma imensa planicie, aberta ao noroeste de se podia ver as serras d'além Paraguassú, e que as serras das Trahiras e da Tapera e os morros do Tamannuá, do Gavião e das Baraunas limitavam e restringiam desde os $60 .^{\circ}$ N.O. até os $54^{\circ}$ N. E. como uma extensa barreira sem solução de continuidade.

Estavamos ainda numa região granitica, cujo aspecto e capacidade são, coa.tudo, inferiores as da chapada de Maracás. Voltamos á uma região secca, em tudo semelhante áquella que tínhamos atravessado antes da Fazenda do Bom Jesus. (SAMPAIO, 1905, p. 171).

Dentro de fazendas sem demarcações com cercas, eram, pois, mais contabilizadas quantas centenas de animais eram criados do que a extensão em terras; isentas, portanto, de cercas perimetrais. Tais fazendas foram resultantes do fatiamento de áreas das sesmarias, possível por meio da Carta Régia de 
1695 que viabilizou sua segmentação em fazendas de dimensões consideráveis correspondendo a três léguas de comprimento por uma de largura, correspondendo a 11.000 hectares de terras.

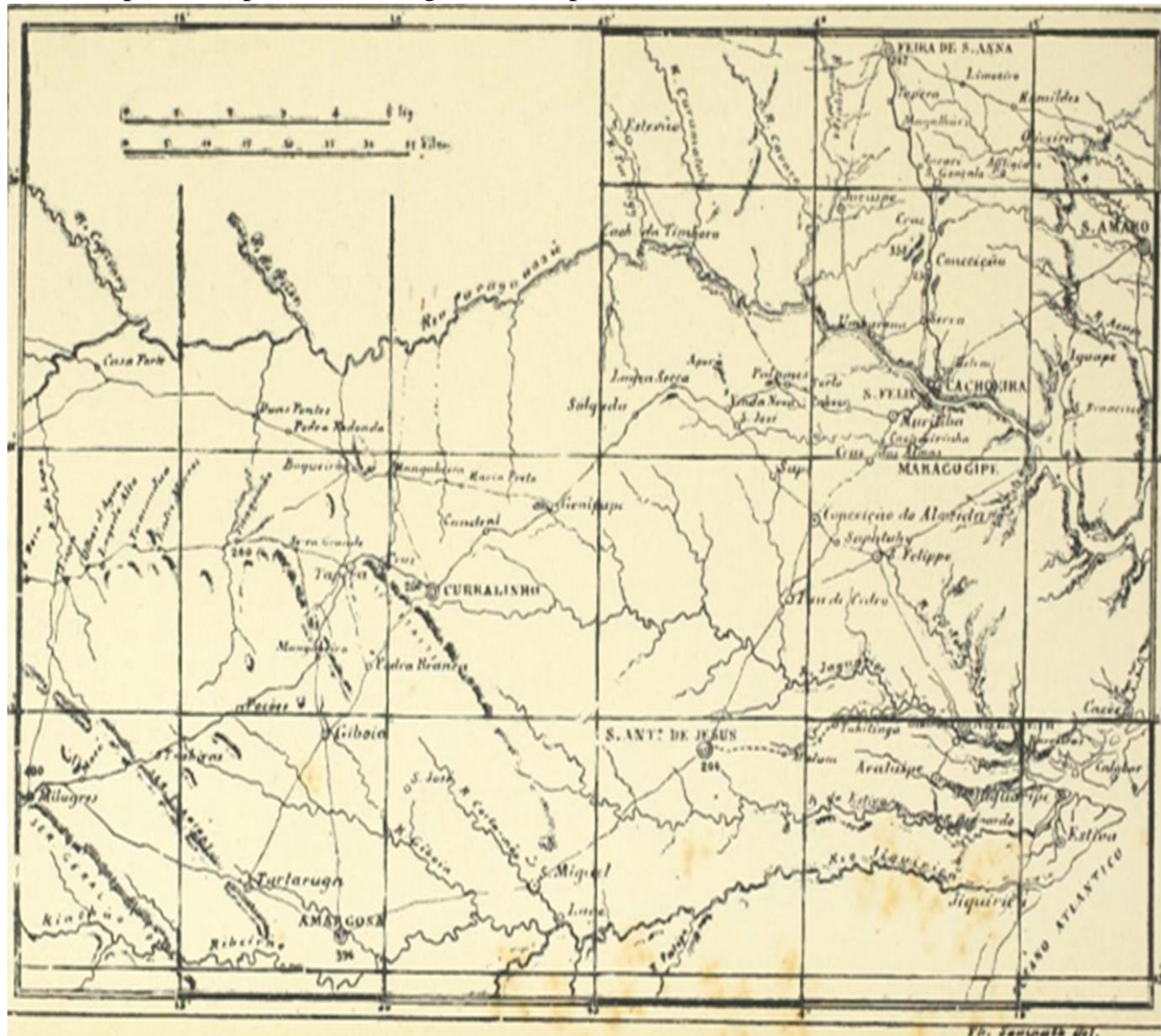

Figura 3: Mapa produzido por Theodoro Sampaio (1905). Exibe área de estudo do Ribeirão do Salgado até Tapera (atual sede do município de Santa Teresinha - BA), canto esquerdo da metade dessa carta geográfica.

Gados adaptados e resistentes: bovinos, ovinos, caprinos e suínos dominavam a paisagem. As raças crioulas, como o bovino curraleiro pé-duro, foram sendo forjadas por meio de cruzamentos não dirigidos (LEAL, 2017; 2018), assim como o carneiro rabo-largo, as cabras e as ovelhas nambi (orelha curta). Surgiram comunidades que se dedicavam aos criatórios, emergindo a emblemática figura de perneira e gibão: o vaqueiro símbolo de resistência, conhecimento e bravura; dotado de poderes místicos, por conta de suas bramuras, paciência, coragem e resistência.

Os vaqueiros eram remunerados por uma forma de pagamento baseada no "sistema de sorte": percebiam a quarta ou quinta. Anualmente, na partição da quarta: de quatro bezerros nascidos, o vaqueiro recebia um; se caso fosse a quinta, de cinco bezerros, o vaqueiro obtinha um (SIMONSEN, 2005; PRADO JÚNIOR, 2008; NASCIMENTO, 2008; CARVALHO; TROILO; FERREIRA, 2020). Por vezes, tal relação promoveu a mobilidade social de alguns vaqueiros. Dessa maneira, o gado bovino amealhado pelos vaqueiros era criado em meio ao rebanho do fazendeiro. O mesmo ocorria com os seus pequenos criatórios de ovinos, caprinos (miunças) e suínos que forrageavam a vegetação da Caatinga: folhas verdes e secas, casca de troncos, frutos e flores da vegetação nativa. Nesse contexto, alguns vaqueiros conseguiam adquirir terras ou arrendá-las.

$\mathrm{Na}$ instalação de pequenos roçados, também eram comuns as relações de parcerias: em sistema de meia, terça ou quarta dada ao fazendeiro ou administrador como pagamento pelo uso da terra (NASCIMENTO, 2012). Relações, portanto, pré-capitalistas. Não se pode deixar de registrar, também, a existência do sistema escravocrata que durou até os fins do século XIX. Esse território, portanto, estava na esteira desse processo. Neles havia o trabalho escravo e livre. Este sob um sistema de pagamento por meação. Adjacente a essa dinâmica, havia pequenas instalações e profissões que eram 
encetadas nesse sistema e.g., ferreiros, carapinas, coureiros, tropeiros, seleiros, oleiros e outras ocupações correlatas ao modus faciendi agropastoril.

\section{Fundo de Pasto - um modo de vida nas caatingas da Bahia}

As relações de meação perduraram até a segunda metade do século $\mathrm{XX}$. $\mathrm{O}$ advento de estradas como a BR 116 (Rio - Bahia), por volta da década de 1950 e 1960, valorizou terras às suas margens e, concomitantemente, foi exarada pelas câmaras municipais a lei dos quatro-fios ou lei de pé alto (ALCÂNTARA e GERMANI, 2010). Esse aparato legal ressoa com intensidade nas caatingas. Por outro lado, mais à frente, na década de 1980, numa conjuntura de ascensão dos movimentos sociais e do processo de democratização do país, surgem resistências com mais relevo, assumindo destaque maior nos territórios do Velho Chico, do Corrente, do Piemonte Norte Itapicuru e ao norte do Sisal, regiões mais distantes da capital e de centros mais dinâmicos economicamente. Porquanto, na atualidade, situa-se a maior parte das comunidades tradicionais de Fundo e Fecho de Pasto reconhecidas oficialmente.

Ressalta-se que o termo Fundo de Pasto é relativamente recente, embora seu modo de vida seja antigo. A adoção e internalização dessa denominação pelos agricultores familiares vêm para exprimir um modo de vida secular da agricultura familiar camponesa na Caatinga. Esses sujeitos convivem com o semiárido, reúnem funções de agroextrativista, de vaqueiro, de agricultor, seus animais pastejam a vegetação nativa em áreas comunais. Possuem expertise em criatórios, especialmente, de caprinos e ovinos, localmente denominados de "miunças", com laços de costumes, parentescos e cuidados comuns com os rebanhos (CAMAROTE, 2011).

Fundo de pasto é um termo incorporado recentemente ao vocabulário local, na acepção de antigas terras livres - terras devolutas -, que se tornaram passíveis de regularização fundiária. Por meio deste são reconhecidas como terras de uso comum, visando à emissão de um título de propriedade em nome de associações comunitárias que representam os interesses dos usuários do fundo de pasto. Pode-se dizer que ele é uma espécie de reminiscência da caatinga livre que se espalhava por largas extensões do sertão adentro. (CAMAROTE, 2011, p. 145).

Destarte, tais camponeses se autoafirmam, adotaram e assumem a terminologia Fundo de Pasto. Tem-se como marco o trabalho das organizações desses sujeitos, com assessoria de setores populares da Igreja Católica, a partir da década de 1980. À época, o país começava a viver o processo de redemocratização e, nesse leito, o ressurgimento político da ação de setores populares (ALCÂNTARA et al., 2011). Pode-se também adotar enquanto referência significativa, nesse caldo social, a ação de agentes do poder público. Decisivamente, trabalhos de regularização de terras, pelo antigo Instituto de Terras da Bahia (INTERBA), corroboraram significativamente tal afirmação da terminologia que também é identitária. Técnicos da Companhia de Desenvolvimento e Ação Regional (CAR), identificados com as lutas dos camponeses e vinculados à Secretaria de Planejamento, Ciência e Tecnologia (SEPLANTEC), publicam o documento intitulado "Projeto Fundo de Pasto - aspectos jurídicos e sócio-econômicos" (BAHIA, 1982). Todo esse contexto contribuiu para que o termo Fundo de Pasto fosse fortalecido e adotado no texto da Constituição da Bahia de 1989, em seu Artigo 178 (BAHIA, 1989).

Portanto, o uso comunal de terras livres, terras soltas, onde os animais de várias famílias/pessoas pastoreiam, está implícito na categoria Comunidade Tradicional de Fundo de Pasto. Nela, pratica-se o agroextrativismo de frutos da Caatinga, coleta de lenha, mel e madeira para alguma necessidade eventual. Além disso, ela traduz um modo de vida particular no semiárido baiano (CARVALHO et al., 2020). Como bem asseverou Camarote (2011):

As comunidades de fundo de pasto constituem, simultaneamente, uma modalidade de ocupação da terra e modalidade de organização social que empreende e anima essa ocupação por meio de um sistema produtivo específico. (CAMAROTE, 2011, p. 148).

Os Fundos de Pasto são, portanto, um modo de desenvolvimento socioterritorial peculiar na sociedade rural brasileira, um caso de etnogênese (LITTLE, 2002) nas caatingas da Bahia. São territórios produzidos por formas de apropriação e uso da terra resultantes de relações comunitárias bem estabelecidas, sendo sociabilidades com níveis de confiança estruturados no parentesco e no compadrio. É mediante a perpetuação de normas específicas instituídas pelos grupos familiares - não somente a terra, mas, todos os recursos são tratados como bem comum a toda comunidade, nunca 
estando dispostos à apropriação e ao controle individual - que os sertanejos mantêm uma unidade territorial.

[...] por sua vez, diz respeito a um conjunto de recursos essenciais - aguadas, fontes e pastagens - que, a despeito de estarem sob domínio privado e serem áreas tituladas, se encontram dispostas a uma apropriação comum. [...] $\mathrm{O}$ acesso à terra não estaria condicionado ao título de propriedade e há casos em que mesmo as que foram terras para cultivo mantêm reses nestes chamados pastos comuns. (ALMEIDA, 2009, p. 55).

A unidade organizativa gerada pelas relações de parentesco e as formas de sociabilidade resultantes têm papel fundamental na permanência das Comunidades de Fundo de Pasto e seu modo de vida na atualidade. Assim, as formas tradicionais de manejo da terra e de seus recursos para a produção da subsistência, por sua vez, acabam sendo o aspecto fundante desse modo de vida, enquadrando-se perfeitamente como sistemas socioecológicos encontrados nas caatingas. Como defendido por Silva et al. (2017, p. 4):

o entendimento de sua dinâmica espacial e temporal é fundamental para a proposição de políticas de desenvolvimento sustentável sólidas que busquem para conciliar melhorias significativas no bem-estar humano, preservando ecossistemas. (SILVA et al., 2017, p. 4).

\section{Apartação por meio das cercas, fim da fartura...}

Na segunda metade do século XX, as instâncias federal e estadual, a fim de darem vazão a novas técnicas e à superação do "atraso", fomentaram o crédito bancário vinculado ao uso de insumos modernos e financiaram projetos agropecuários com pastagens exóticas. Ademais, foi disseminada a algaroba (Prosopis juliflora), espécie exótica originária de áreas desérticas do Peru, Bolívia e Chile, com pastagens como pangola (Digitaria eriantha), buffelgrass (Cenchrus ciliaris) e braquiária (Urochloa decumbens). Estas ações estavam lastreadas com o aval de órgãos públicos de ensino, pesquisa e extensão. Bastante recorrente foi o processo de desqualificação dos conhecimentos/saberes dos camponeses, bem como os seus agroecossistemas e raças locais.

Por seu turno, em nível municipal, as câmaras aprovaram leis que impuseram restrições às modalidades de criações soltas na Bahia. Resulta disso a obrigação de os criadores conterem seus animais por meio de cercas. Sem embargo, foi o anteparo jurídico que quase findou o regime de criatórios soltos na Caatinga, em grande parte dos municípios na Bahia; alargou a instalação de cercas perimetrais de grandes áreas pelos fazendeiros mais ricos; restringiu os pequenos criatórios dos agricultores familiares e expulsou pessoas do campo para as cidades; extinguindo agroecossistemas seculares, caracterizados pelo forrageamento do componente animal nas caatingas de modo solto, livre, sem cercas, com raças crioulas com práticas de manejo tradicional no semiárido. Tal processo foi consolidado em inúmeras regiões. De fato, pode-se incluir como exemplo o território dos inselbergues de Milagres, Brejões, Itatim e Iaçu e suas circunvizinhanças. Isso foi bem ilustrado por um depoimento de um idoso, ex-morador das Traíras, em Itatim - BA.

[...] até início de 60 (1960) era comum existir rebanho de gado, cabra, ovea e até porco sorto na Caatinga. Eles comiam as folhas e ramagens da Caatinga, os cachos de licurioba e licuri maduro. Existia fartura nas Traíras, mas depois das cerca acabou, diminuiu o criatoro e muita gente saiu para cidade (Seu Guilhermino, agricultor, Itatim - BA).

Para a manutenção dessa estrutura secular de pastoreio na Caatinga, onde abundam plantas nativas leguminosas e frutas como licuri, ariri, araticum (Annona sp.), umbu (Spodias tuberosa), quixaba (Sideroxylon obtusifolium), favela (Cnidoscolus obtusifolius) e incontáveis leguminosas (Fabaceae), foi fundamental o regime de parceria entre os donos das terras e administradores/vaqueiros e os criatórios formados por raças crioulas ou locais. Assim, os rebanhos de bovinos, caprinos, ovinos e suínos criados soltos foram elementos presentes desse modo de viver nas caatingas. O bovino pé-duro, epíteto conferido a uma raça brasileira, adquirido por conta de os animais resistirem ao calor e à escassez de água em determinados períodos do ano, ao chão duro e à vegetação espinhosa, além de forragearem plantas xerófilas da Caatinga, foram descritos fenotipicamente como pequenos e sem cupim, garupa de pouca expressão e cujos ancestrais são espécimes de raças da Península Ibérica como a mirandesa e barrosã (DOMINGUES, 1942; PRIMO, 2000; EGITO et al., 2002; LEAL, 2018; CARVALHO et al., 2020), portanto, pertencente à subespécie Bos taurus ibericus. 
Nas décadas de 1950 e 1960, o projeto de modernização conservadora do campo brasileiro fomenta raças de alto desempenho zootécnico e colabora para a extinção de muitas raças nativas. A despeito disso, Domingues (1942), embora defensor do gado indiano no âmbito de desenvolvimento de uma ciência zootécnica tropical, já havia alertado sobre possíveis problemas quanto ao azebuamento do rebanho: processo implementado com a castração dos machos pés-duros, e colocavam touros zebuínos como reprodutores. Sob a ótica desse pesquisador, essa não seria necessariamente a solução desejada. Ele chegou a expor que a perda de uma raça nativa (como é o bovino pé-duro) seria irreparável até mesmo culturalmente, além da perda de qualidades próprias como rusticidade e adaptabilidade ao manejo e às condições locais.

Assim, ampliou-se o latifúndio, desmontaram-se agroecossistemas tradicionais, acarretando na expulsão da população do campo. Grande parcela da Caatinga veio abaixo por tratores para implantação de pastagens com gramíneas exóticas. Quanto às raças animais, adotaram-se terminologias generalistas como o SRD (Sem Raça Definida) para o rebanho local. Mormente, o imaginário das raças "de fora" foi reforçado, pois já se fazia presente entre os fazendeiros. Tanto assim, que os cruzamentos com os zebuínos já eram vistos com bons olhos pelos pecuaristas. Ainda no século XIX, registrou-se o aparecimento do termo rês "gadomar", ou "guademar", e de mestiços raceados com sangue de zebu (Bos taurus indicus), possivelmente advindo de rebanhos de regiões africanas. Há documentos, nas fazendas dos Dantas, das reses gadomá (NASCIMENTO, 2008; 2012). À frente, em meados do século XX, os zebuínos vindos de Minas atingiram a porção norte tanto do Centro-Oeste quanto do Nordeste brasileiro, causando a quase extinção da raça pé-duro curraleiro que obteve registro oficial recente, em 2012, conferido pelo Ministério da Agricultura, Pecuária e Abastecimento - MAPA, após reunião no final de 2011.

No roldão do projeto modernizante do campo, ampliou-se, como dito anteriormente, a supressão da vegetação natural mecanizada para dar lugar às pastagens. Ressalta-se que uma das características do bioma Caatinga é a ocorrência de estiagens recorrentes; as pastagens com gramíneas exóticas não resistiram e, por conseguinte, perderam-se as forragens nativas, resultando na redução da capacidade de suporte animal. No aspecto físico, as terras se tornaram mais compactadas e ressecadas, com maior escassez de água, depauperação dos solos e ressurgimento, em algumas áreas, de uma vegetação empobrecida ou com solos desnudos. Assim ocorreu na porção do pediplano sertanejo, área que abarca os municípios de Milagres, Itatim, Nova Itarana e Iaçu, região detentora de uma ocupação humana antiga, denotada pelas inscrições rupestres existentes (Figura 2D) e endemismo, principalmente, no alto dos inselbergues, como as Euphorbiaceae, Bromeliaceae, Solanaceae, dentre outras como as Cactaceae e Orchidaceae (FRANÇA et al., 1997).

\section{Na tábua, as orelhas das criações e, na ponta da faca, sinais e marcas de identidade}

Com efeito, as reses teriam que ser identificadas quanto ao seu dono, pois eram criadas livres nas caatingas, formando os rebanhos de inúmeros criadores. Decerto, por uma herança trazida da Península Ibérica, os fazendeiros imprimiram as marcas de famílias, especificadas por meio de cortes ou sinais nas orelhas dos animais. Assim era possível distinguir os donos das reses, as famílias a que os animais pertenciam. Evento semelhante foi registrado em vários pontos de criações soltas no Brasil: no faxinal, no Paraná (CHANG, 1988); nos pampas, na fronteira entre o Rio Grande do Sul e Uruguai (FLORES, 2014); no sertão de Caicó, no Rio Grande do Norte (DINIS, 2008) e no Vaza-Barris, na Bahia (NASCIMENTO, 2008). Convém informar, inclusive, que há marcas e nomes, assemelhados aos utilizados no semiárido, chegando a compor livros de registros de órgão públicos da época, assim como os ferros no couro do gado, marcas que traziam denominações de fazendas de famílias, não raras vezes, proprietárias de heranças.

Há alusão a tais marcas nos criatórios na cultura popular, tal como no cordel publicado no início do século XX: A História do Boi Misterioso, do paraibano Leandro Gomes de Barros (19-?, p.8)

\footnotetext{
"Pois bem disse o coronel

Esse garrote encantado

Quando apareceu

Inda não estava ferrado

Foi orelhudo de tudo

Nem sequer estava assinado
}

\author{
Pois tem na orelha esquerda \\ Três mossas e um canzil \\ Tem na orelha direita \\ Brinco lascado e funil \\ O ferro da Santa Rosa \\ Esta nele a marca buril"
}




\section{ETHNOSCIENTIA}

ETHNOSCIENTIA V. 5, 2020

www.ethnsocientia.com

ISSN: 2448-1998

D.O.I. 10.22276/ethnoscientia.v5i1.320

Assim, por meio de entrevistas semiestruturadas com os agricultores, cujo registro

foi realizado por vídeos em celulares, com depoimentos, no primeiro semestre de 2020, com desenhos ilustrativos, foram obtidas explicações dos agricultores acerca de como eram feitas as marcas ou sinais nas orelhas das criações. Elas possuíam a capacidade de identificar as famílias cujas reses ou pequenos criatórios pertenciam, chegando a afirmar as "assinaturas" dos proprietários em seus criatórios.

Dentre os sinais mais recorrentes, foram apontados: forquilha ou "furquia" (Figura 4C), botoque, mossa, coice de porta (Figura 4B), ponta aparada (Figura 4A), ponta de candeeiro, arpão, garfo (Figura 4E) e brinco.
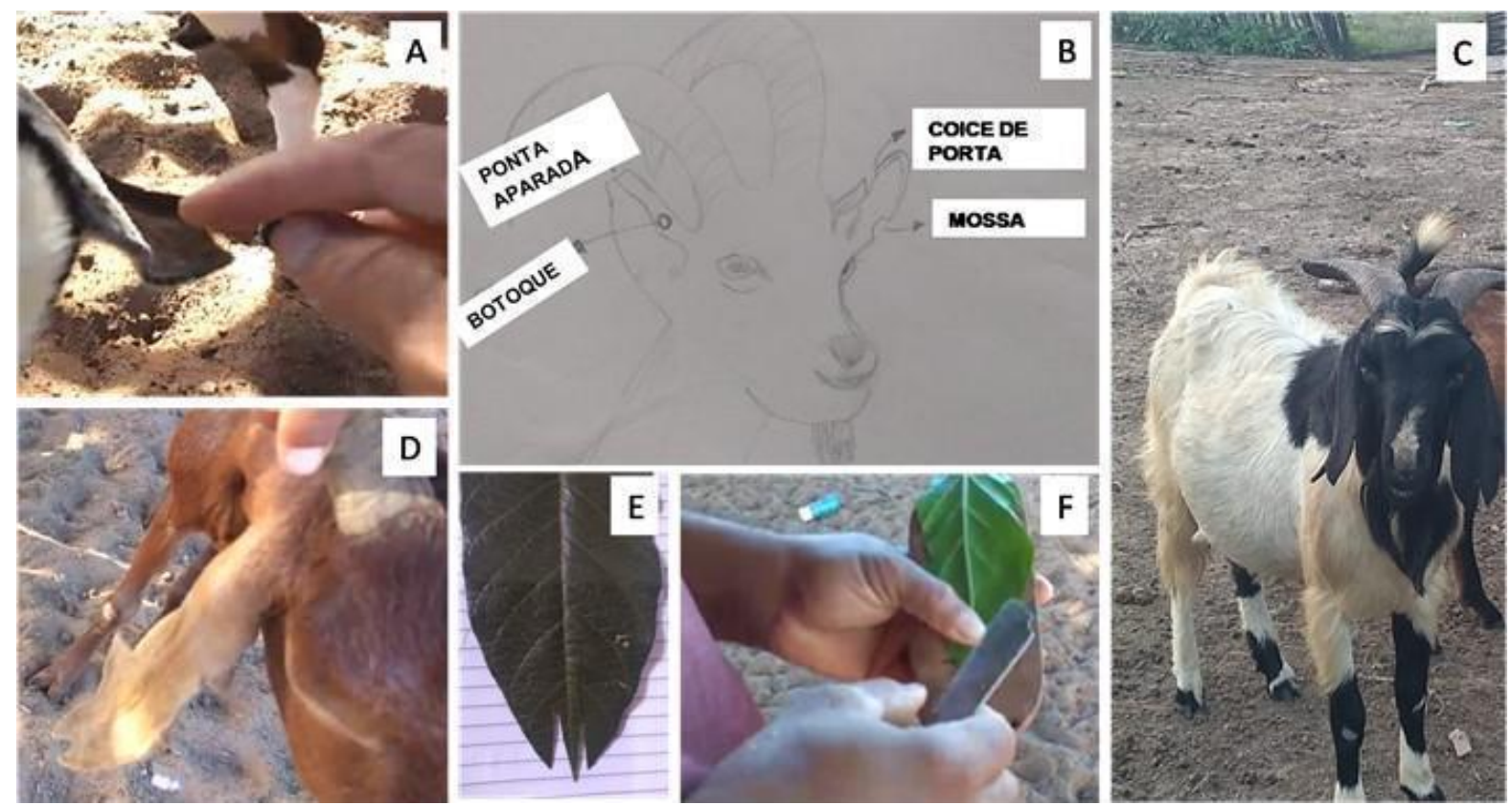

Figura 4: Sinais ou marcas distintivas nas orelhas de caprinos. (A) Ponta aparada, Faz. Jatobá, Brotas de Macaúbas - BA; (B) desenho esquemático de sinais feito por Antonio Neto da Hora, Faz. Jatobá, Milagres - BA; (C) bode com sinal de forquilha, Comunidade de Fundo de Pasto de Caraíba, Monte Santo - BA; (D) sinal distintivo de família, Comunidade de Fundo de Pasto de Jatobá, Brotas de Macaúbas - BA; (E) folha ilustrando o sinal chamado garfo; (F) tábua sobre a qual a orelha do animal era disposta para marcação.

Era comum, em uma das orelhas, a marca da família, a exemplo do florete, palmatória ou um conjunto de marcas similares e, em outra, era possível identificar o proprietário(a) mesmo de longe, ao observar o rebanho na capoeira. O procedimento, na Comunidade Fundo de Pasto do Jatobá, em Brotas de Macaúbas - BA, que consistia na marca de família, utilizava-se de uma pequena tábua, sobre a qual se dispunha a orelha do borrego/cabrito, e se fazia a prática de cortes ou sinais distintivos (Figura 4F). Na orelha direita, assinalava-se a marca da família e, na esquerda (Figura 4D), a divisa, que significa a que membro da família pertence o animal (Figura 4A). Zambrini (2016), em seu trabalho de mestrado no sertão pernambucano, em Floresta, identifica o mourão como prática semelhante, uma vez que ele seria a marca e a assinatura da família; seria um sinal na orelha do animal que identificava o proprietário.

Informações assemelhadas também foram coletadas na cidade de Monte Santo, em comunidades tradicionais de Fundo de Pasto, no entorno da Lagoa do Mandacaru, e na Comunidade de Fundo de Pasto de Barriguda e Jatobá, em Brotas de Macaúbas. Os relatos apontam que as marcas ou os sinais nas orelhas dos criatórios são "assinaturas", verdadeiros registros de identidade das famílias e das pessoas nos rebanhos. Interessante é que esses distintivos também foram encontrados em Milagres, onde os rebanhos soltos remontam ao final da década de 1950, porém ainda vivos na memória de pessoas mais idosas da comunidade do Jatobá (Milagres - BA) e Traíras (Itatim - BA), situada às margens da BA 046, entre Amargosa e o trevo da BR 116.

A depender de sua disposição na orelha do animal, assimilam a nomenclatura do conjunto como florete; palmatória, apontados na pesquisa de campo (Figura 5). Foi verificado que o padrão adotado pelas comunidades Fundo de Pasto de Monte Santo e Macaúbas, conforme exemplo exposto na Figura $5 \mathrm{~A}$, é repetido nas comunidades pesquisadas em Milagres e Itatim, região foco do presente estudo (Figura 5B, 5C, 5D, 5E e 5F). 
Essa forma de sinalização para identificar a quem pertence os animais, especialmente, caprinos e ovinos, com a "assinatura" (Figura 5) nas orelhas, é utilizada por comunidades tradicionais, na Bahia (LIMA, 2008). No Nordeste, encontram-se registros de relatos nos Estados de Pernambuco (NASCIMENTO, 2010; ZAMBRINI, 2016, VASQUES, 2019), Rio Grande do Norte (ARAÚJO et al., 2006; DINIZ, 2008) e, no Sul do país, podem citar trabalhos de Chang (1988) e de Kosby (2017). Em todos os casos, os autores se referem às marcações como uma forma ou prática que caracterizava a criação de rebanhos em regime de solta, sem as cercas divisórias ou perimentais, como é o caso das comunidades de Fundo de Pasto existentes na Bahia.
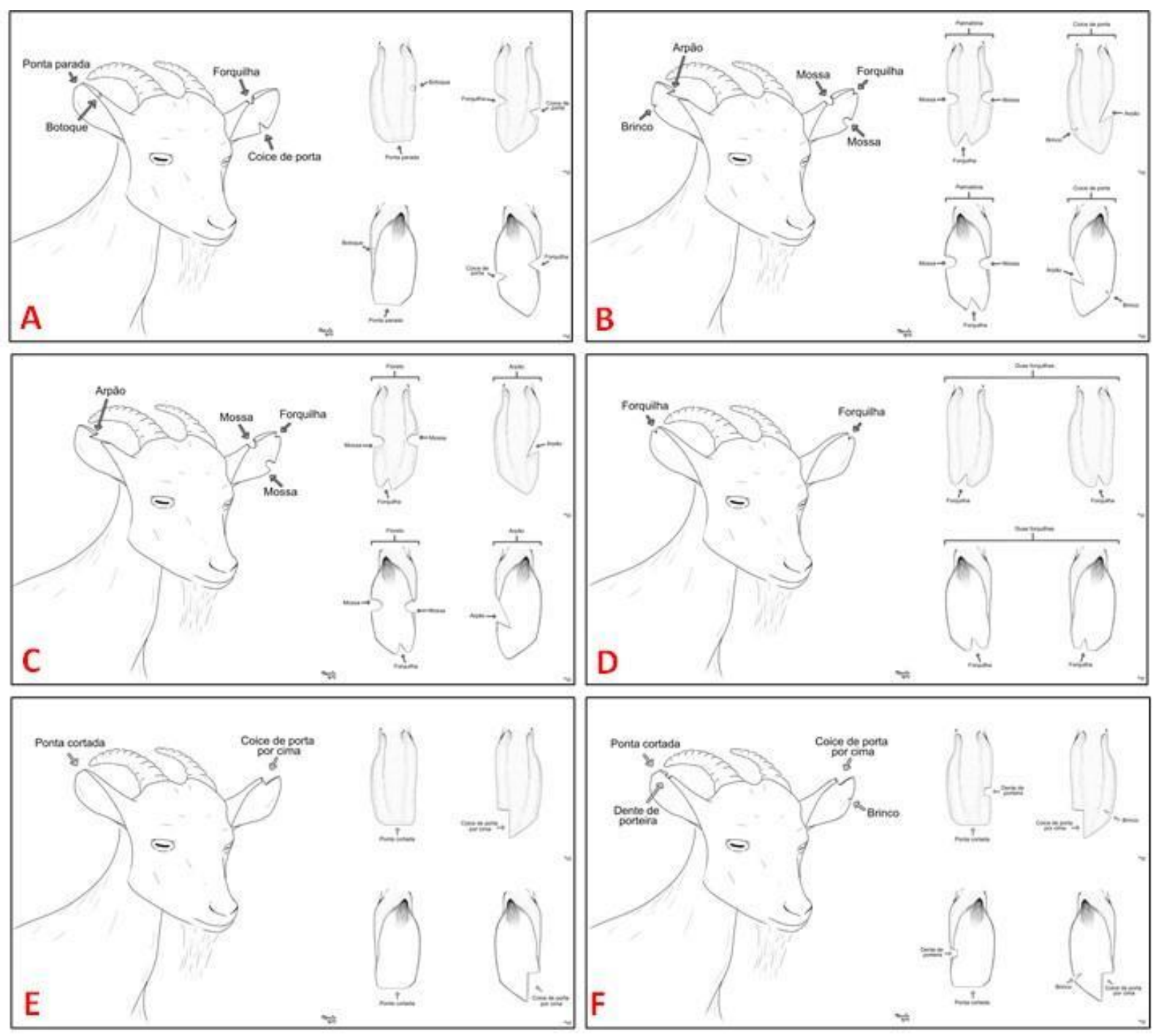

Figura 5. Desenho esquemático representativo das "assinaturas" nas orelhas dos animais, nas comunidades Fundo de Pasto: (A) marcações de Monte Santo; (B) Marcações da família Ferreira da Silva; (C) marcações da família João Alexandre Filho, (D) marcações da família de Melquias Ferreira da Silva; (E) marcações da família de Manoel Pereira Bahia; (F) marcações da José Edimisom Dantas Bahia. Fonte: Pesquisa de campo. Elaboração dos desenhos: Pâmella Kelly Andrade Barreto, 2020.

Nesse regime de criação de animais, torna-se digno de nota, deve-se fazer referência à existência de cercas nas imediações de Tartaruga e Gameleira (distritos do atual Município de Milagres - BA), em Lagoa do São João e Lajedo Grande (Distrito de São Roque, no Município de Amargosa)e na Passagem do Lajedo (distrito de Itachama), que separava a área de solta de gado das áreas de plantios, que eram os "travessões", designação da época. Estas cercas eram marcos impeditivos, cuja finalidade era separar, estabelecer fronteiras entre os rebanhos soltos e as áreas de roças. As áreas de cultivo eram mais comuns nas baixadas ou se situavam em outras glebas mais úmidas do beira-campo, ecótono entre a caatinga e a mata, com predomínio de plantios em relação aos criatórios. Os travessões, na maioria das vezes, eram mantidos por quem plantava as roças. 


\section{NA MALHADA DOS FINALMENTES}

São perceptíveis as conectividades intercomunitárias da agricultura familiar camponesa, seja na ocupação do território, no rastro de seu processo colonizatório, seja denotado por narrativas e práticas de manejo dos rebanhos. Existem, portanto, similaridades no modus vivendi das comunidades tradicionais de Fundo de Pasto, mesmo que distantes geograficamente e disjuntas da área foco, situadas nas caatingas, nos atuais territórios do Jiquiriçá e do Piemonte do Paraguaçu.

No território entre os vales do Paraguaçu e Jiquiriçá, restou vivo na memória um território sequestrado, já que o movimento de desconstrução e desmonte, dos agroecossistemas de criatórios soltos na Caatinga, foi consolidado e extinto em momento histórico-político no qual as forças populares detinham menores espaços de organização e expressão. Portanto, num espaço temporal anterior ao processo ocorrido em comunidades tradicionais de Fundo de Pasto, oficialmente, reconhecidas.

Afora os aspectos históricos e biofísicos de formação do território agropastoril, baseado nas criações soltas forrageando a Caatinga, um traço de semelhança identificado no estudo foram os sinais ou cortes nas orelhas das reses, uma prática aparentemente simples, mas que foi estabelecida por conta da existência de uma materialidade de inexistência de limites de propriedades por meio de cercas. Essa prática ainda persiste nas Comunidades Tradicionais de Fundo de Pasto, mas restou apenas na memória de pessoas na região entre os vales do Paraguaçu e Jiquiriçá.

Ademais, necessita-se ampliar tais estudos, com aprofundamento e caracterização, sistematização de componentes e práticas existentes nos agroecossistemas locais, de modo a fortalecer vínculos identitários que contribuam para a valorização da agricultura familiar camponesa, suas formas organizativas e mecanismos de resistência, a fim de garantir territórios tradicionais socioambientalmente sustentáveis.

\section{REFERÊNCIAS}

ABREU, J. de C. Capítulos de história colonial. Sociedade Capistrano de Abreu. Rio de Janeiro: Briguiet, 1934.

AB'SÁBER, A. N. Os domínios de natureza no Brasil: potencialidades paisagísticas. São Paulo: Ateliê Editorial, 2003.

AB'SÁBER, A. N. A organização natural das paisagens inter e subtropicais brasileiras. In: SIMPÓSIO SOBRE O CERRADO, 3., 1971, São Paulo. Anais... São Paulo: Edgard Blücher/Edusp, 1971. p. 1-14.

ALCÂNTARA, D. M.; GERMANI, G. I.; SAMPAIO, J. L. F. Há uma lei no meio do caminho: luta para permanecer na terra nos fundos e fechos de pasto. Terra Livre, v. 2, n. 37, p. 74-103, 2011.

ALCÂNTARA, D. M.; GERMANI, G. I. As comunidades de fundo e fecho de pasto na Bahia: luta na terra e suas espacializações. Revista de Geografia, v. 27, n. 1, p. 40-56, 2010.

ALMEIDA, A. W. B. de. Terras de preto, terras de santo, terras de índio - uso comum e conflito. In: GODOI, E. P. de; MENEZES, M. A. de; MARIN, R. A. (orgs.). Diversidade do campesinato: expressões e categorias. v. 2. São Paulo: editora Unesp/UnB, 2009. p. 39-66.

ARAÚJO, M. J. M.; MEDEIROS; V. M.; MACEDO, H. A. M. de. Couro marcado a ferro e fogo: cotidiano e vivência da marca de ferrar gado no Seridó potiguar. Mneme revista de humanidades, v. 8, n. 20, p. 125-165, 2006.

AZEVEDO, G. S. de. Leituras, notas, impressões e revelações do Tratado descritivo do Brasil em 1587 de Gabriel Soares de Sousa. Rio de Janeiro: UERJ, 2007.

BAHIA. [Constituição (1989)]. Constituição do Estado da Bahia. Salvador: EGBA, 1989.

BAHIA, PDRI - Nordeste Projeto Fundo de Pasto Aspectos Jurídicos e Sócios Econômicos. Salvador: CAR/SEPLANTEC, 1982.

BANDEIRA, L. A. M. O feudo: a casa da torre de Garcia d'Ávila: da conquista dos sertões à independência do Brasil. 3 ed. Rio de Janeiro: Civilização Brasileira, 2015.

BARROS, L. G. de. A história do boi misterioso. São Paulo: Luzieiro Editora Limitada, 19-?.

BLENGINI, I. A. D.; FERREIRA, J. de M. L.; CINTRA, M. A. M. U. (org.). Trilhando a Serra da Jiboia venha desvendar sua importância e seus mistérios. Salvador: Gambá, 2015.

BONDAR, G. Importância econômica das palmeiras nativas do gênero Cocos nas zonas secas do interior baiano. Bahia: Instituto de Fomento Econômico da Bahia, 1939.

BRASIL. Ministério das Minas e Energia. Secretaria Geral. Folha SD 24. Salvador: geologia, geomorfologia, pedologia, vegetação, uso potencial da terra. Rio de Janeiro, v. 24, 1981.

CAMAROTE, E. M. Territorialização e parentesco em uma comunidade baiana de fundo de pasto. Ruris, v. 5, n. 1, 2011.

CARVALHO, A. J. A. de; TROILO, G.; FERREIRA, M. H. dos S. (org.). Comunidades tradicionais de Fundo de Pasto: território de riqueza agrobiocultural e convivência com o Semiárido. Salvador: Áttema, 2020. 
CARVALHO, A. J. A, de. LICURI, Syagrus coronata (Mart.) Becc.: associações micorrízicas, estrutura de desenvolvimento e epifitismo como subsídios ao manejo sustentável. 2019. Tese (Doutorado em Ciências Agrárias) - Universidade Federal do Recôncavo da Bahia, Cruz das Almas, 2019.

CHANG, M. Y. Sistema faxinal: uma forma de organização camponesa em desagregação no centro-sul do Paraná. Londrina: Iapar, 1988.

CUNHA, M. C. da (org.). História do índio no Brasil. 2. ed. São Paulo: Companhia das Letras, 1992.

DINIZ, N. M. M. Velhas fazendas da ribeira do Seridó. 2008. Dissertação (Mestrado em História e Fundamentos de Arquitetura e Urbanismo) - Faculdade de Arquitetura e Urbanismo, Universidade de São Paulo, São Paulo, 2008.

DOMINGUES, O. O gado nativo do Brasil: as supostas raças bovinas. Revista de Agricultura, p. 71-78, 1942.

EGITO, A. A.; MARIANTE, A. S.; ALBUQUERQUE, M. S. M. Programa brasileiro de conservação de recursos genéticos animais. Archivos de Zootecnia, v. 51, p. 39-52, 2002.

FIORAVANTI, M. C. S. et al. Reintrodução do gado curraleiro na comunidade quilombola Kalunga de Cavalcante, Goiás, Brasil: resultados parciais. In: SIMPÓSIO INTERNACIONAL DE SAVANAS TROPICAIS, 9., E SIMPÓSIO NACIONAL DO CERRADO, 2., 2008, Brasília. Anais... Brasília: Embrapa, 2008, v. único. CD-ROM.

FLORES, M. F. da C. T. Crimes de fronteira: a criminalidade na fronteira meridional do Brasil (18451889). Porto Alegre: Edipucrs, 2014. E-book. Disponível em: <https://editora.pucrs.br/Ebooks/Pdf/978-85-3970481-1.pdf>. Acesso em: 09 jul. 2020.

FRANÇA, F.; SANTOS, E.; SANTOS, C. C. Flora de inselbergs da região de Milagres, Bahia, Brasil: I. caracterização da vegetação e lista de espécies de dois inselbergs. Sitientibus, n. 17, p.163-184, 1997.

FURTADO, J. F. Homens de negócio: a interiorização da metrópole e do comércio nas minas setecentistas. 2. ed. São Paulo: Hucitec, 2006.

INEMA, INSTITUTO DO MEIO AMBIENTE RECURSOS HIDRICOS. Regiões de planejamento e gestão das águas - RPGA e solos. Secretaria de Meio Ambiente, Governo do Estado da Bahia, 2014. p. 1. Disponível em: <http://www.inema.ba.gov.br/wp-content/files/MTematico_solos.pdf>. Acesso em: 25 maio 2020.

KING, L. A geomorfologia do Brasil oriental. Rev. Bras. Geogr., v. 18, n. 2, p. 147-265, 1956.

KOSBY, M. F. Alma-caroço: peregrinações com cabras negras pelo extremo sul do Brasil. 2017. Tese (Doutorado em Antropologia Social) - Instituto de Filosofia e Ciências Humanas, Universidade Federal do Rio Grande do Sul, Porto Alegre, 2017.

LEAL, N. S. Dos manuais que fazem raça: técnicas e enunciados sobre purezas zootécnicas. R@U, v. 10, n. 1, p. 25-52, 2018.

LEAL, N. S. De sangues, purezas e misturas bovinas: políticas e saberes da criação. In: COMERFORD, J.; BEZERRA, M. O.; PALMEIRA, M. (org.). Questões e dimensões da política: anais do Encontro dos 20 anos do Núcleo de Antropologia da Política (NuAP). Rio de Janeiro: Papéis Selvagens, 2017.

LIMA, K. C. Caprinovinocultura e agricultura familiar no semiárido baiano: um olhar sobre o programa cabra forte. 2008. Dissertação (Mestrado em Desenvolvimento Sustentável) - Centro de Desenvolvimento Sustentável, Universidade de Brasília, Brasília, 2008.

LINHARES, M. Y. L. História agrária. In: CARDOSO, C. F. S. Domínios da história. 3. ed. São Paulo: Campus, 2015

LITTLE, P. Territórios sociais e povos tradicionais no Brasil: por uma antropologia da territorialidade. Brasília: UnB, 2002.

NASCIMENTO, R. de B. Caracterização morfoestrutural e dos sistemas de criação da raça moxotó em seu centro de origem com base no conhecimento local. 2010. Dissertação (Mestrado em Zootecnia) Universidade Federal Rural de Pernambuco, Recife, 2010.

NASCIMENTO, J. M. "Terra, laço e moirão": relações de trabalho e cultura política na pecuária (Geremoabo, 1880-1900). 2008. Dissertação (Mestrado em Filosofia) - Instituto de Filosofia e Ciências Humanas, Universidade Estadual de Campinas, Campinas, 2008.

NASCIMENTO, J. M. Vaqueiros e fazendeiros na comarca de Geremoabo - Bahia no final dos oitocentos: Geremoabo - Bahia no final dos oitocentos: trabalho, dominação e resistência. Revista Mundos do Trabalho, v. 4, n. 8, p. 161-181, 2012.

NEVES, E. F. das. Formação territorial, ocupação econômica e divisão dos poderes nas Serranias Centrais da Bahia. Feira de Santana: UEFS, 2019.

PEREIRA, L. F. Da poesia oral ao cordel: nota sobre a transformação narrativa de uma poesia popular nordestina. Letras, v. 27 n. 55, p. 143-171, 2017.

PRADO JÚNIOR, C. Formação do Brasil contemporâneo (Colônia). 26. ed. São Paulo: Editora Brasiliense, 2008. 
PRIMO, A. T. The discovery of Brazil and the introduction of domestic animals. In: GLOBAL CONFERENCE ON CONSERVATION OF DOMESTIC ANIMAL GENETIC RESOURCES, 5, 2000, Brasília. Proceedings [...]. Brasília: Embrapa Genetic Resources and Biotechnology, 2000. p. 4.

PUNTONI, P. A Guerra dos bárbaros: povos indígenas e a colonização do sertão. Nordeste do Brasil, 1650-1720. São Paulo: Hucitec-Edusp/ Fapesp, 2002.

REGO, A. de A. Cabilda de facinorosos moradores: uma reflexão sobre a revolta dos índios da Pedra Branca de 1834. 2009. Dissertação (Mestrado em História Social) - Faculdade de Filosofia e Ciências Humanas da Universidade Federal da Bahia, Salvador, 2009.

SAMPAIO, T.. O Rio de S. Francisco e a Chapada Diamantina: trechos de um diário de viagem (187980), São Paulo: Escola Profissionaes Salesianas, 1905.

SANTOS, J. M. dos; SAlGADO, A. A. R. Gênese da superfície erosiva em ambiente semiárido. Milagres/Ba: considerações preliminares. Revista de Geografia, Recife, v. 27, n. 1. Esp. 236-247, 2010.

SANTOS, M.. Da totalidade do lugar. São Paulo: Edusp, 2008.

SANTOS, S. N. A. dos. Conquista e resistência dos Payayá nos sertões das Jacobinas: Tapuias, Tupi, colonos e missionários (1651-1706). Salvador: UFBA, 2011.

SIBCS. Sistema Brasileiro de Classificação de Solos. 5. ed. Brasília: Embrapa, 2018.

SIMONSEN, R. C. História econômica do Brasil, 1500-1820. 34. ed. Brasília: Senado Federal, Conselho Editorial, 2005.

SILVA, J. M. C. da; BARBOSA, L. C. F.; LEAL, I. R.; TABARELLI, M. The Caatinga: understanding the challenges. In: SILVA, J. M. C. da; LEAL, I. R.; TABARELLI, M. (eds.). Caatinga: the largest Tropical dry forest region in South America. Suiça: Springer, 2017. p. 3-19.

SOUSA, G. S. Tratado descritivo do Brasil em 1587. 5. ed. São Paulo: Cia. Editora Nacional, 1987.

THIOLLENT, M. Metodologia da pesquisa-ação. São Paulo: Editora Cortez, 2000.

VASQUES, A. Sinais, os sobrenomes da criação. Revista Florestan, v. 5, n. 7, p. 11-20, 2019.

VERDEJO, M. E. Diagnóstico rural participativo: guia prático DRP. 3. ed. Brasília: MDA / Secretaria da Agricultura Familiar, 2010.

ZAMBRINI, A. V. As veredas do bode: criação na solta e laboro no sertão de Pernambuco. 2016. Dissertação (Mestrado em Antropologia Social) - Universidade Federal de São Carlos, São Carlos, 2016. 